\title{
Heidegger a Hegelova Fenomenológia
} ducha

\section{Heidegger and Hegel's Phenomenology of Spirit}

\author{
Kristína Bosáková
}

\begin{abstract}
Abstrakt
Fenomenológia ducha, zdôrazňuje Heidegger, je prvou čast'ou Hegelom plánovaného systému vied. Jej podtitul znie: Veda o skúsenosti vedomia. Tou vedou (Wissenschaft) bude filozofia, chápaná ako veda o skúsenosti vedomia, teda o skúsenosti, ktorú má vedomie seba samého. Filozofii, podl'a Hegela, ide o absolútne poznanie, teda o poznanie $\vee$ najvšeobecnejšom zmysle slova. Možno teda tvrdit', že kým Hegelovi išlo vo Fenomenológii ducha o vztah človeka, poznávajúceho subjektu, schopného sebauvedomenia, k absolútnu, tak Heideggerovi v jeho interpretácii Hegelovej Fenomenológie ducha išlo predovšetkým o absolútno samé, teda o bytie, ako ho chápal. Pre Heideggera nie je problematika obsiahnutá vo Fenomenológii ducha ničím iným ako artikuláciou protikladu: nekonečnost' bytia verzus konečnost' jestvujúcna.
\end{abstract}

\section{Kl'účové slová}

bytie, jestvujúcno, sebauvedomenie, absolútno, duch

\begin{abstract}
Phenomenology of Spirit, Heidegger says, is the first part of the system of science that was planned by Hegel. Another of its titles is called: Science of the Experience of Consciousness. By the science (Wissenschaft) is meant philosophy, understood as a science of the experience of consciousness, which means an experience that the consciousness makes with itself. According to Hegel, philosophy is attempting to get an absolute knowledge, the most general knowledge that is possible to achieve. And meanwhile for Hegel, in his Phenomenology of Spirit, the relationship to the human being, as a subject that is able to get an absolute
\end{abstract}


knowledge and to achieve the self-consciousness, is the most important, Heidegger prefers in Hegel's Phenomenology of Spirit Being itself with its relationship to beings as he understood it. For Heidegger all of the problems from the Phenomenology of Spirit represent nothing less than an articulation of the endless Being compared to the variety of temporal beings.

\section{Keywords}

being, beings, self-consciousness, absolute, spirit

Heidegger sa Hegelovej filozofii venuje prakticky počas celého svojho filozoficky aktívneho života. „Heideggerovo zaoberanie sa Hegelom začína skoro a končí neskoro. Heidegger sa pravdepodobne so žiadnym iným filozofom nezaoberal tak kontinuálne ako s Hegelom." $\mathrm{Z}$ Heideggerovej tvorby je zrejmé, že najvýraznejšiu konfrontáciu Heideggera s Hegelom predstavujú najmä Heideggerove neskoré texty, ako Onto-teo-logická štruktúra metafyziky (1956-1957), Hegel a Gréci (1958) alebo Koniec filozofie a úloha myslenia (1962), texty, z ktorých je zrejmé, že ,jediným zdatným konkurentom, s ktorým Heidegger zviedol ostrý filozofický zápas o ontologické problémy, mohol byt len Georg Wilhelm Friedrich Hegel". ${ }^{2}$ Ciel'om tejto štúdie však nebude zmapovat’ ten časový úsek, v ktorom Heidegger venuje najviac pozornosti Hegelovmu modelu metafyziky ako logiky, ${ }^{3}$ ale obdobie, ktoré sa najmä v našich domácich, česko-slovenských podmienkach teší menšej bádatel'skej pozornosti, teda to medzi rokmi 1930 až 1943, ked' Heidegger upriamuje svoju pozornost̉ na Hegelovu Fenomenológiu ducha.

Okrem analýzy Hegelovej Fenomenológie ducha ako vedy o skúsenosti vedomia, v prednáškach z roku 1942/43 sa Heidegger špeciálne venuje tomuto spisu už omnoho skôr, a to vo svojich Freiburských prednáškach zo zimného semestra na prelome rokov 1930/31. Fenomenológia ducha, zdôrazňuje Hei-

1 Peter Trawny, Heidegger and German Idealism, in F. Raffouls - E. S. Nelsons (eds.), The Bloomsbury Companion to Heidegger, London - New York: Bloomsbury Publishing Plc 2013, s. 113-120: 113. Peter Trawny si vo svojej štúdii Heidegger a nemecký idealizmus všíma nielen význam Hegelovej filozofie pre vývoj Heideggerovho vlastného myslenia, ale aj zanietenost', s akou sa Heidegger neustále vracia k Hegelovým textom. Heidegger je na dlhé roky kritickým a velmi húževnatým čitatelom Hegela. Trawny zároveň upozorňuje na skutočnost', že Heidegger najskôr radí nestotožňovat Hegelovu dialektiku so samotnou Fenomenológiou ducha a neskôr ich dokonca dôrazne rozlišuje.

2 Vladimír Leško, Metafyzika. Heidegger verzus Hegel, Košice: Vydavatel'stvo UPJŠ 2015, s. 7.

3 Tamže. 
degger, je prvou častou Hegelom plánovaného systému vied. Jej podtitul znie: Veda o skúsenosti vedomia. Už z podtitulu práce je zrejmé, že Hegelov systém vedy nebude predstavovat len sumu celého dovtedajšieho poznania, nazhromaždeného prevažne novovekými prírodnými vedami, ale že mu pôjde o vedu vied (Wissenschaft), teda o vedu, ktorej úlohou bude posúdit a neskôr spochybnit alebo odobrit všetky dovtedajšie spôsoby poznávania. Tou vedou (Wissenschaft) bude filozofia, chápaná ako veda o skúsenosti vedomia, teda o skúsenosti, ktorú má vedomie seba samého. Poznanie čiastkových, najmä prírodných vied je poznaním relatívnym, svoj význam má iba vo vztahu k poznávanému. Filozofii však, podla Hegela, ide o absolútne poznanie, teda o poznanie v najvšeobecnejšom zmysle slova. Toto poznanie sa vztahuje $\mathrm{k}$ absolútnu samému, pričom možnost' poznania absolútna, teda absolútneho poznania, určuje všetky d’alšie možnosti čiastkového poznania konkrétnych vied.

„Nakol'ko si systém vedy vyžaduje ako svoj prvý diel »Fenomenológiu ducha«? Čo mieni tento podtitul? Kým zodpovieme túto otázku, musíme pripomenút, že ani tento podtitul diela, ktorý sa neskôr stal jediným, nie je úplný. Celý názov diela najprv znel: »Systém vedy. Prvý diel. Veda o skúsenosti vedomia.« Tento podtitul - »Veda o skúsenosti vedomia - je neskôr uvedený v tvare: »Veda fenomenológie ducha«. Až odtial’ vyrastá skrátená a neskôr bežne zaužívaná »Fenomenológia ducha«."4

Hegelova veda vied by mala mat dve časti. Obe spolu nielen úzko súvisia, ale aj argumentačne neustále poukazujú jedna na druhú. Prvou je Fenomenológia ducha ako veda o skúsenosti vedomia, druhou je Logika ako veda, pričom Heidegger zdôrazňuje, že obidve nie sú ničím iným ako vyjadrením tradičnej metafyziky, ktorú možno vo všeobecnosti charakterizovat ako ontológiu, tvorenú čiastkovými vedami, ako špekulatívna kozmológia, špekulatívna psychológia a špekulatívna teológia. Hegel sa, podla Heideggera, venuje vo svojej metafyzike konkrétne špekulatívnej kozmológii ako filozofii prírody a špekulatívnej psychológii ako filozofii ducha, pričom špekulatívna teológia sa uňho menovite nespomína. To však neznamená, tvrdí Heidegger, že by sa v Hegelovom diele špekulatívna teológia nevyskytovala. Naopak, je od počiatku prítomná v jeho ontológii, pričom práve Hegelova Logika predstavuje spojenie ontológie s teológiou. ${ }^{5}$

4 Martin Heidegger, Hegels Phänomenologie des Geistes, GA. Bd. 32, Frankfurt am Main: Vittorio Klostermann 1997, s. 3.

Tamže, s. 4. 
Než sa Heidegger dostane k celkovej interpretácii Fenomenológie ducha, určuje si teoretické východiská pre ním predpokladaný dialóg s Hegelom. „Dielo je absolútny celok skúsenosti, ktorú musí vedenie vykonat'v sebe samom a v ktorej sa samo sebe stáva zjavným ako Duch, ako absolútne vedenie, ktoré túto skúsenost’ v základe tvorí. "6 Nielen názov a podtitul Hegelovej Fenomenológie ducha, ale celý obsah spisu je podla Heideggera paradoxne možné adekvátne pochopit až z jeho Logiky. Vo Fenomenológii ducha sa absolútny duch dostáva $\mathrm{k}$ sebe samému $\mathrm{v}$ procese neustálych protirečení, na základe ktorých vyjavuje seba samého tak, že predstavujúce a predstavované sa stáva jedným. Duch sa takto dostáva k svojmu vlastnému elementu, ktorým je éter. Až v Logike sa Absolútny duch prostredníctvom dialektického pohybu dostal do oblasti (Bereich) svojej vlastnej ríše (Reich).

„Z tohto v tomto druhu pohybu sa rozvíja oblast' (Bereich) jeho ríše (seines Reiches). Táto oblast̉ ale nie je žiadnym vonkajším ohraničením polí, odsekov a obvodov, ktoré musia byt ešte vyplnené, ale oblast̉ a jej vnútorná výstavba je skutočnostou samotného Absolútneho ducha, ktorá sa sama vystavia a do výstavby zabuduje to, čo sa na jeho ceste zjaví. Toto zjavovanie preto nie je žiadnym obmieňaním sa podôb vedomia, ale je ako absolútne dejiny absolútneho ducha pohybom, v ktorom sám seba traduje a túto tradíciu ruší (aufhebt) - ruši v trojakom, u Hegela vždy sa vznášajúcom význame tohto slova: tollere - odobrat a zbavit sa prvotného čistého zdania, conservare, uchovat', poňat do skúsenosti, ale ako nejaké elevare - ako pozdvihnutie na vyšší stupeň vedenia seba samého a svojho vedeného. "7

Fenomenológia ducha, uvádza Heidegger, je systémom absolútneho vedenia, ktoré absolútne vie o sebe samom. Len absolútne vedenie, ktoré je vedené absolútne, môže byt považované za vedu, a aj napriek tomu, že pojem vedomia je tu chápaný transcendentálne, nemožno Hegelovu Fenomenológiu ducha stotožňovat s Husserlovou fenomenológiou. Ďalším častým omylom je predpoklad, že Fenomenológia ducha predstavuje akúsi typológiu vedomia, avšak bez znalostí modernej psychológie a sociológie, alebo že predstavuje úvod do filozofie, charakterizovaný ako prechod od zmyslovo-predmetného poznávania k špekulatívnemu mysleniu. „Stále a znova si musime hovorit: Hegel už od počiatku predpokladá to, čo získava na konci. "8 Podl’a Heideggera to

$\begin{array}{ll}6 & \text { Tamže, s. } 37 . \\ 7 & \text { Tamže, s. } 39 . \\ 8 & \text { Tamže, s. } 43 .\end{array}$


však v žiadnom prípade nie je zo strany Hegela trúfalost’ ani znak arogancie, ale predpoklad, ktorý vychádza zo samej podstaty filozofie.

\section{Vedomie a zmyslová istota}

Zmyslová istota tvorí u Hegela prvý stupeň poznávania a vztahuje sa k nej prvá čast̉ analýzy poznávacieho procesu ako skúsenosti vedomia. Pre Hegela predstavuje tú najmenej spolahlivú, no zároveň tú najbohatšiu formu poznania. ${ }^{9}$ Túto prvú čast', hovorí Heidegger, nemožno interpretovat ani obvyklým spôsobom, ani tak ako zvyšné dve časti, pretože si vyžaduje špeciálny prístup. Zmyslová istota je tým, čo vytvára prvotný predmet poznávania, je vnímaním a prijímaním jestvujúcna tak, ako sa bezprostredne, navonok bezo zmeny ukazuje naším zmyslom. Ak predmetom Fenomenológie ducha, tvrdí Heidegger, je vedenie, potom je zmyslová istota tým prvotným predmetom pre nás. Čo však znamená prvotný predmet, čo znamená bezprostredné poznávanie a vedenie a čo znamená to pre nás? Môže to pre nás znamenat pre kohokolvek, kto práve začal čítat Hegelovu Fenomenológiu ducha? To sú otázky, ktoré si Heidegger kladie, aby na nich vzápätí odpovedal:

„Nie, ale tí »my«, to sú tí, ktorí už začiatku vedia absolútne a týmto spôsobom toto vedenie chápu a určujú... Ten predmet pre nás, náš predmet, je predmet pre tých, ktorí už od počiatku vieme $t a k$, že sa správame sprostredkúvajúco, t. j. spôsobom už charakterizovaného uchovania (Aufhebens), pričom samo toto pozdvihovanie je druhom diania absolútneho vedenia, ktoré má charakter tohto nepokoja, ktorý je absolútny a ktorý Hegel nazýva »absolútnou Negativitou« alebo »nekonečnou afirmáciou«. Čo to znamená, sa ukazuje vo »Fenomenológii ducha«. Teraz len tol'ko: $\mathrm{V}$ tomto vedení nie je vediaci postoj nikdy jednoduchým pritakaním a nikdy jednoduchým, neústupným odporovaním, ale ani výlučne tým nie toho áno a to áno toho nie, ale tým, čo ako vnútorný zákon spočíva v negácii negácie. To bezprostredné je podla už povedaného to, čo pre nás, tých sprostredkúvajúcich, pre naše sprostredkovanie ešte nie je sprostredkované." 10

Bezprostredné poznanie však musí byt’ sprostredkované sprostredkovaným poznaním, a to tak, že sa to sprostredkované zníži (herablassen) k smerom

9 Georg Wilhelm Friedrich Hegel, Fenomenologie ducha, prel. Jan Patočka, Praha: Vydavatelství Československé akademie věd 1960, s. 103.

10 Tamže, s. 66. 
bezprostrednému, prostredníctvom uchovania (Aufhebung), ktoré má charakter pozdvihnutia. „To bezprostredné je už tým bez-prostredným tohto sprostredkovania."11 Toto zníženie sa sprostredkovaného sa deje tak, že sa my, ako tí, ktorí vedia vedu, nebudeme brat tak vážne a takpovediac ponecháme stranou (herbeilassen) seba samých. Aký je potom ten prvotný predmet vedenia pre nás, teda ten, ktorý máme prijímat (aufnehmen) bezprostredne, bez pohybu, ktorý inak spôsobuje prirodzený nepokoj (Unruhe) dialektického pohybu myšlienky a ktorý istým spôsobom spočíva (ruht) aj v tom bezprostrednom, ktoré by týmto pohybom ešte nemalo byt nijako dotknuté? Hegel, zdôrazňuje Heidegger, označuje dva predmety vedenia, vedenie pre ono a vedenie pre nás, pričom vedenie pre ono je prirodzenou súčastou vedenia pre nás, ktoré je vedením vedenia. Tým prvotným a bezprostredným predmetom vedenia tak má byt jestvujúcno.

\section{Vnímanie}

Ked' sa teda chceme k Hegelovej Fenomenológii ducha a k jeho dialektike viac priblížit, musíme sa hned' na začiatku vyzbrojit vel'kou dávkou trpezlivosti. Fenomenológia ducha ako veda o skúsenosti vedomia je opisom jednotlivých fenoménov ducha, ako spôsobov, akými sa Absolútny duch v priebehu svojich dejín zjavuje. Duch sa spočiatku zjavuje bezprostredne, ako istota zmyslového vnímania, ktorá sa však vedomiu nejaví ako bezprostredná, ale už ako sprostredkovaná.

„Absolventné pozorovanie zmyslovej istoty nám udalo: Podla spôsobu svojho vedenia mieni jednotlivé toto; ale jej pravda, ktorú vyslovuje už v samotnom slove >toto<, je všeobecnom. Tým, že myslí jednotlivé, neponíma svoje pravdivé; nie je vnímaním (Wahrnehmung), a predsa ním už istým spôsobom je - pokial' má to pravdivé pri sebe, avšak bez toho, aby si to privlastňovala. Zmyslová istota tak už sama od začiatku potvrdzuje právo a nutnost’ vnemu, t. j. absolventné vedenie zmyslovej istoty je cezeň vyhnané k vedeniu vedenia ako vnemu."12

Dôležitý je pritom najmä náš čitatel'ský a interpretačný prístup, zdôrazňuje Heidegger. My musíme hned' spočiatku zohladnit', že celý text Fenomenológie ducha už začína z pohladu absolútna a my sme tí, ktorí musíme

11 Tamže, s. 67.

12 Tamže, s. 112. 
okamžite praktizovat absolventnú rekonštruujúcu konštrukciu. Ako však dokážeme my, konečné bytosti, pýta sa Heidegger, postihnút niečo, čo je vo svojej podstate vyjadrením nekonečna? Len tak, tvrdí, že sa necháme unášat samotným textom, že sa budeme aktívne zúčastňovat dialektického pohybu kladením vhodných otázok a hladaním odpovedí na ne. Ak totiž utíchne kladenie zodpovedajúcich otázok, utíchne aj samotný text a nevyjaví nám viac svoje posolstvo. Text musi byt' stále živý a živé musi byt' aj kladenie našich otázok. Kladením otázok a hladaním odpovedí posúvame vpred dialektický pohyb, teda pohyb, ktorý na základe sústavných prechodov kladie otázku bytia a hladá na ňu odpoved'.

„Čo ale Hegela a nás tlačí rovnakým spôsobom do pohybu, je otázka po bytnosti bytia. Druhy pýtania sa a odpovedania sa križujú. Hegel si tú otázku nekladie, ale dáva odpoved' na otázku po podstate jestvujúcna, ktorá už dávno vznikla z vnútornej nutnosti tradície a odpovedá so základnou tézou: je to nekonečnosṫ... Vysvetlíme, ako vzniká nekonečnost’ »je « jednoduchej výpovedi ako určenia niečoho ako niečoho. Táto nekonečnost’ nemieni zaradom postupujúce hromadenie sa určení, do nekonečna napred od jedného k druhému, ale naopak: návrat niečoho do seba samého, obrat nejakého určitého smerom do seba samého tak, že sa to určité ako iné vráti spät do jedného a že zároveň to iné pojme do seba ako od seba odlišné tak, že sa v jednote s ním stane nerozlíšeným a v identite s ním zostane uchované."13

Prechod od zmyslovej istoty k rozumu tvorí vnímanie. Vnímanie je zároveň tým, čo z bezprostredného poznania vytvára poznanie sprostredkované, a to tak, že rozumu sprostredkováva to bezprostredné zmyslovej istoty, čím vytvára d’alší, celkom nový predmet poznania pre nás. Zatial' čo pri zmyslovej istote ešte nedochádza $\mathrm{k}$ odlíšeniu predmetu poznania od poznávacieho procesu, tak v prípade vnímania je už zretel'né odlíšenie procesu vnímania od vnímaného predmetu. Vnímanie, konštatuje Heidegger, však nie je sprostredkovaným poznaním iba preto, lebo rozumu posúva alebo odovzdáva predmet zmyslovej istoty, ale aj preto, lebo sa nachádza v prostriedku, medzi zmyslovou istotou a rozumom. Platí to ale aj opačne, vnímanie rovnako ako zmyslovú istotu sprostredkováva aj rozum.

13 Tamže, s. 113. 


\section{Sila a Rozum ${ }^{14}$}

Skutočné poznanie je absolútnym poznaním a absolútne poznanie je pre Heideggera ontoteológiou. Absolútne poznanie je vždy už poznaním sprostredkovaným, avšak nie v tradičnom zmysle slova, ale tým, že má bezprostredný vztah k stredu (Mitte) a deje sa vždy vo vzţahu k tomuto stredu, definované-

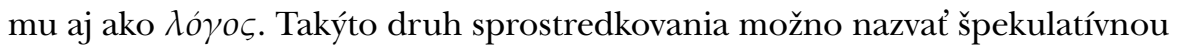
pravdou. Špekulatívna pravda je prekonaním protirečivosti jednostranného poznania nielen pridaním pohladu z druhej strany, ale je úplným zjednotením perspektív na základe hladania prvého v druhom a druhého v prvom prostredníctvom špekulatívneho je (ist), ktoré je zároveň bytím a predstavuje absolútne sprostredkovanie. Táto absolútna jednota v rozdvojení sa nazýva štastie a je úplným prekonaním (Aufheben) neštastia, ktoré vzniká v dôsledku rozdvojenia. Pozdvihnutie neštastia $\mathrm{k}$ štastiu spočíva v zmierení a následnom oslobodení sa jestvujúcna v jeho bytí.

„Špekulatívne uchopená a teda zdôvodnená interpretácia bytia je ontológia,

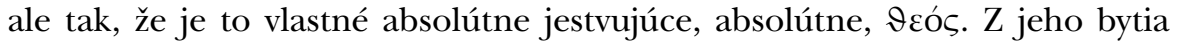

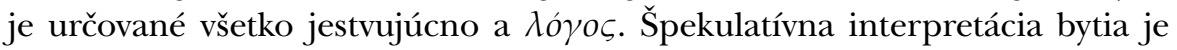
onto-teo-lógia. Tento výraz nemá hovorił len to, že je filozofia orientovaná na teológiu, alebo že je sama takou, v zmysle už na začiatku prednášky vysvetleného pojmu špekulatívnej alebo racionálnej teológie... Vieme tiež, že už Aristoteles priviedol filozofiu vo vlastnom zmysle slova do najužšej súvislosti

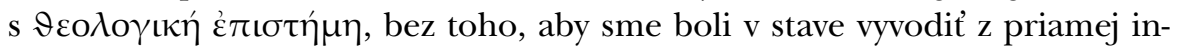
terpretácie skutočné závery o súvislosti medzi otázkou po ôv ᄁ̃ ôv a tou po

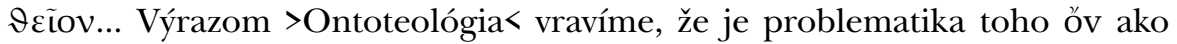
logická v prvom a poslednom rade orientovaná na $\vartheta \varepsilon$ cos, ktorý je pritom už sám pochopený »logicky« - ale logicky v zmysle špekulatívneho myslenia: [...] Z pohladu veci je to tak, že podstata Boha ako ducha vôbec načrtáva podstatu pojmu a tým charakter logického. “15

14 V slovenskom preklade Fenomenológie ducha sa pojem Verstand prekladá ako um. V tomto texte je tento pojem preložený ako rozum, ked’že ho Heidegger dáva do priamej súvislosti $\mathrm{s}$ rozumenim (Verstehen, Verständigtum) a porozumením (Verständnis). Navyše Hegel nerozlišuje tak prísne pojmy Verstand a Vernunft, ako to robí Kant. Pozri G. W. F. Hegel, Fenomenológia ducha, prel. Patrícia Elexová, Bratislava: Kalligram 2015, s. 97 a 124. Patočka vo svojom preklade používa výraz schopnost rozvažovat. K Patočkovmu prekladu Hegelovej Fenomenológie ducha pozri bližšie aj Róbert Stojka, Hegelova filozofia dejín, in Vladimír Leško - Viera Schifferová - Róbert Stojka - Pavol Tholt (eds.), Patočka a novoveká filozofia, Košice: UPJŠ 2014, s. 317-318.

15 M. Heidegger, Hegels Phänomenologie des Geistes..., s. 141-142. 
Podla Heideggera ide Hegelovi v jeho Fenomenológii ducha primárne o problém bytia a akákolvek problematika óv je u Hegela nutne spojená s $\vartheta \varepsilon o ́ s$, avšak v prísne logickom zmysle slova. No ani logiku nechápe Heidegger v súlade s tradíciou, a tak logický znamená pre neho predovšetkým špekulatívny a spojený s $\lambda o ́ \gamma o \zeta$. Hegelov Absolútny duch, okrem toho, že predstavuje zmierenie a zjednotenie jestvujúcna v jeho bytí, je zároveň pojmom, ktorý má postihnút podstatu Boha. Ak by sme $\lambda o ́ \gamma o \varsigma$ chápali ako pojem, potom práve Boha možno charakterizovat ako pojem pojmov, a teda ako ten

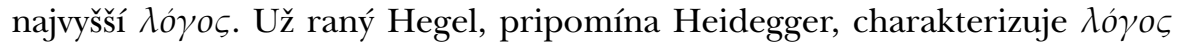
ako absolútne sebauchopenie vedenia (absolutes Sichbegreifen des Wissens). ${ }^{16} \mathrm{Z}$ toho jednoznačne vyplýva: „Rozumiet’ niečo z podstaty Boha znamená: pochopit to pravé logické tohto logu a naopak."17 Takýmto výkladom $\lambda o ́ \gamma o \varsigma$ Hegel pozdvihol a zároveň zrušil chápanie $\lambda o ́ \gamma o \varsigma$, ktoré vládlo v tradičnej logike, ale bez toho, aby túto logiku úplne odstránil.

Hegelova filozofia, ktorá je rovnako nemyslitel'ná bez krestanskej teológie ako i bez antickej metafyziky, preto nie je nejakým druhom mystiky, ale naopak, je prísne logicky konštruovaným systémom, aj ked' podla Heideggera v pozitívnom zmysle slova prekračuje hranice tradičnej logiky. Heidegger sa pritom odvoláva na svoje vlastné dielo Bytie a čas, ktoré podla jeho vlastných slov predstavuje celkom nové uchopenie problému bytia tak, že pojem $\lambda o ́ \gamma o \varsigma$ zamieňa za pojem $\chi \rho o ́ v o \varsigma$ a namiesto tradičnej ontológie hovorí o ontochrónii. Na rozdiel od Hegela, ktorý pojem vidi ako moc v čase, je Heidegger presvedčený, že je to práve čas, ktorý dáva pojmu jeho moc. ${ }^{18}$ Rovnako Hegela kritizuje pre jeho tradičné, aristotelovské chápanie času. Napriek tomu, tvrdí Heidegger, má Hegelova filozofia ako onto-teo-lógia len málo spoločného a tradičnou krestanskou teológiou a už vôbec ich nemožno zamieňat'. V pojme onto-teo-lógie ide o prísne filozofickú súvislost’ medzi logom a bytím, v ktorej sa odzrkadluje špekulatívno-dialektický charakter celej Hegelovej filozofie.

Čo má teda Hegel na mysli, ked’ hovorí o sile (Kraft) nejakej veci (Ding)? Pojem sily, zdôrazňuje Heidegger, má u Hegela vyjadrovat bytnost’ (Wesen) danej veci, jej substanciu. Substancialita substancie potom znamená najmä to, ako (wie) je konkrétne jestvujúcno k dispozícii (vorhanden), ako funguje vo svojej existentia, vo svojom pobyte (Dasein), v skutočnosti. ${ }^{19}$ „Pojem síly

\footnotetext{
16 Tamže, s. 142.

17 Tamže.

18 Tamže, s. 144.

19 Tamže, s. 147.
} 
se naopak udržuje jako bytnost ve své skutečnosti samé; síla jako skutečná je naprosto pouze v projevu, který zároveň není nic jiného než překonáním sebe. “20 Trojicu, pozostávajúcu zo substanciality, kauzality a ich vzájomného pôsobenia, nazýva Hegel reláciou (Relation), vztahom (Verhältnis), výrazom, ktorý podla Heideggera nie je akýmsi neutrálnym pojmom, ako tomu bolo u Kanta, ale tak ako všetky hegelovské pojmy má prísne špekulatívny význam. Hegel totiž neurčuje len kategórie substancie a kauzality zo vztahu, ale pomocou pojmu sily sa snaží odkryt aj podstatu vztahu samého. Vztah (Verhältnis) napriek tomu, že je vyjadrením nepodmienenosti, nie je lubovolným alebo náhodným vztahovaním sa k niečomu (Beziehung), je tým, čo drží (hält) jednotlivé jestvujúcna pohromade, je tým, čo spôsobuje, že sa každé konkrétne jestvujúcno správa (verhält) spôsobom, ktorý vedie k prekonaniu mnohosti a následnému zjednoteniu.

Vzṫah je tým všeobecným, ktoré drží v sebe všetky jednotlivé jestvujúcna ako ich spoločný základ a ich jednota. Len vd’aka vztahu môžu byt konkrétne jestvujúcna skutočne tým, čím sú. Sila ako vztah však nie je čírym vyjadrením kauzality, ked’že túto kauzalitu síce zahŕňa, ale zároveň ju aj výrazne prekračuje. Sila a vztah tvoria nepodmienenú pravdu danej veci, tú, ktorá v zjednotení protikladov prekonáva jej podmienenú pravdivost́. Sila ako nepodmienené všeobecné sa tak stáva predmetom rozumu, ktorý tým tiež získava charakter nepodmieneného, všeobecného poznania a je špekulatívne určovaný ako nekonečný. Hegel tým podla Heideggera prekonáva Kantom zavedenú konečnost’ rozumu a rozumového poznania.

\section{Sebauvedomenie}

Rozum, podla Heideggera, nie je ešte schopný pochopit’ nekonečnost̉ ako takú, napriek tomu, že na ňu neustále naráža, a to v procese sebauvedomenia. Najkratším a najvýstižnejším vyjadrením Hegelovho chápania nekonečnosti je pre Heideggera Hegelova veta: Ja sa rowná Ja. V tejto vete Hegel zretel'ne vyjadruje, že logiku nemožno oddelit’ od Ja, lebo len Ja môže mat'

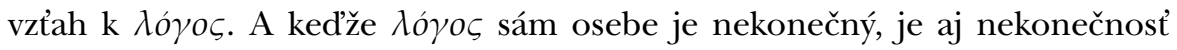
myslenia bytostne spojená s Ja. „Skutočnosṫ nekonečna je subjekt, t. j. v absolútnom zmysle $d u c h . "{ }^{21} \mathrm{~K}$ pochopeniu nekonečnosti dochádza až vtedy,

20 G. W. F. Hegel, Fenomenologie ducha..., s. 129.

21 M. Heidegger, Hegels Phänomenologie des Geistes..., s. 114. 
ked' si Ja uvedomí, že je pri sebareflexii odlišné Nie-Ja, cudzie pre seba samé a zároveň je stále tým istým Ja, teda identické so sebou samým. Ja dokáže takto pochopit’ seba samé iba vtedy, ak k sebe pristupuje z perspektívy absolventného poznania.

Podla Heideggera nebolo Hegelovým zámerom dokázat ani vyvrátit, že každé vedomie je zároveň sebauvedomením a že jedno bez druhého nemôže prakticky jestvovat'. Hegel, upresňuje Heidegger, sa nepohybuje v takomto prirodzenom nastaveni, ale už od počiatku pristupuje k problematike sebauvedomenia z pozície absolútneho poznania. Preto, ked' hovorí, že vedomie je sebauvedomenim, má skôr na mysli odkrytie toho, že sebauvedomenie je pravdou vedomia ${ }^{22} \mathrm{v}$ prísne špekulatívnom význame. „Nebot mysliti neznamená být pro sebe předmětem jako abstraktni já, nýbrž jako já, které má současně význam byti o sobě, čili vztahovati se k předmětné bytnosti tak, že má význam byti pro sebe toho vědomí, pro které jest. " ${ }^{23}$ Vedomie je sebauvedomením v rovnakej miere, ako je filozoficky, dialekticky a špekulatívne poňatý rozdiel identitou a rôznost’ zároveň jedným, ku ktorému sa neustále imanentne vztahuje. Podstata rôznosti totiž vždy spočíva v jednote a jednota je zakaždým zjednotením protikladných určení na základe istej spolupatričnosti. Z tohto pohladu je pre Heideggera prechod od vedomia a smerom k sebauvedomeniu vlastne návratom k podstate vedomia samého, ked’že existenciu vedomia umožňuje podla neho až sebauvedomenie. No Hegel, hovorí Heidegger, neostáva pri jednoduchom zistení, že vedomie nie je možné bez sebauvedomenia, ale ide ešte d’alej, ked' vo svojej dialektike d’alej rozvíja a zároveň tak prekonáva Kantovu syntetickú jednotu transcendentálnej apercepcie. ${ }^{24}$

„Sebauvedomenie je iba prechodom. Samo je ešte relatívnym v rámci nekonečnosti, ktorá má byt poňatá v pojme jej úplnej pravdy. Tým je rozhodnuté aj toto: sebauvedomenie sa u Hegela od počiatku nikdy priamo nezobrazuje ako oblast' predbežných bytostných súvislostí zážitkov v zmysle obvodu možnej výskumnej práce, ale ide o skutočnost’ ducha. V krátkosti: nejde o byt'-sám-vedomý (Selbst-bewußt-sein) ako to, čo má byṫ reflexívne vedené, ale o seba-uvedomenie ako vyššiu skutočnost’ oproti bytiu predmetov, ktoré sú pre vedomie k dispozícii. Platí, priniest́ bytie seba (das Sein des Selbst), to bytie sebou (das Selbstsein) $\mathrm{k}$ absolventnému porozumeniu. “25 Heidegger sa takto prostredníctvom

22 Tamže, s. 193.

23 G. W. F. Hegel, Fenomenologie ducha.., s. 162.

24 M. Heidegger, Hegels Phänomenologie des Geistes..., s. 194.

25 Tamže, s. 195-196. 
Hegela a jeho sebauvedomenia (Selbstbewußtsein) dostáva od bytia sebou (Sein des Selbst) k bytiu samému (das Sein selbst) a jeho antickej interpretácii cez $\lambda o ́ \gamma o \varsigma$, neskôr z dôvodu nepochopenia v pýtaní sa na vedomie a poznanie, rozšírenej o oblast' Ja (ego, Ich, Selbst).

Robert Sinnerbrink ale upozorňuje na skutočnost', že takáto interpretácia Hegelovho sebauvedomenia nie je z Heideggerovej strany správna, pretože Heidegger pri nej neberie do úvahy hladisko intersubjektivity, ktoré sa v Hegelovom pojme sebauvedomenia rozhodne nachádza. Hegel, podla Sinnerbrinka, definuje vo Fenomenológii ducha sebauvedomenie ako súbor univerzálneho, jednotlivého a individuálneho. „Kým Heidegger zdôvodňuje prvý moment (abstraktnú seba-identitu toho 'Ja' ako Ja = Ja) a druhý moment (jednotlivost' seba-uvedomenia ako žiadostivost'), nemá zdôvodnenie pre tretí moment (konkrétnu individualitu, artikulovanú prostredníctvom intersubjektívneho uznania). Vskutku, Heideggerovo zlyhanie pri vysvetlovaní momentu konkrétnej individuality v pojme seba-uvedomenia tvorí jasnú paralelu s nedostatkami kantovsko-fichteovského vysvetlovania seba-uvedomenia, ktoré sa Hegel snaží prekonat prostredníctvom svojho vysvetlenia úlohy vzájomného uznania. $\mathrm{V}$ tomto zmysle Heidegger, rovnako ako Kant a Fichte, zostáva v uvažovaní o seba-uvedomení zaseknutý na úrovni reflexie, ked' v súlade s abstraktným formalizmom: formuluje nedostatočnú koncepciu seba-uvedomenia, ktorá nedokáže zjednotit všetky tri momenty, teda univerzalitu, jednotlivost’ a zásadný, tretí moment individuality, získanej v procese uznania." ${ }^{26}$

Hegelova dialektika je tak pre Heideggera špecifickým spracovaním problému bytia, ktoré je spočiatku založené na filozofickej tradícii, ktorá nekonečnost bytia spája s problematikou logu, pričom dialektický pohyb ako nesvojvolné spájanie protikladov, vychádza práve zo zakorenenosti bytia v logu. Takéto chápanie dialektiky vychádza z gréckej a teologickej myslitel'skej tradície. Druhý spôsob chápania nekonečnosti, zdôrazňuje Heidegger, vychádza u Hegela rovnako z logu, avšak z takého logu, u ktorého po descartovskom ob-

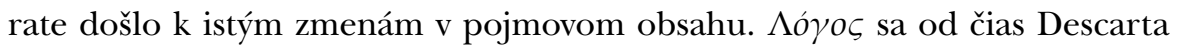
dáva do súvislosti najmä s novovekým chápaním ratio a orientuje sa omnoho viac smerom k ego, ku cogitatio, k vedomiu a k Ja. Substancia sa potom stáva pravdou subjektu a subjektom je aj Absolútny duch, čím sa obsah metafyziky

26 Robert Sinnerbrink, Sein und Geist: Heidegger's Confrontation with Hegel's Phenomenology, Cosmos and History: The Journal of Natural and Social Philosophy, Vol. 3, 2007, No. 2-3, s. 136. 
síce nijako výrazne nemení, no ona sama sa jemne vychyluje zo svojho pôvodného smerovania.

Heideggera však vôbec nezaujíma Hegelovo chápanie pojmu Ja ako súčast' a výsledok procesu sebauvedomenia, pretože on sám považuje Fenomenológiu ducha za konečné štádium možného zdôvodnenia ontológie. Preto je, podla neho, výsledkom procesu sebauvedomenia čisté bytie, ktorého korene siahajú až do čias antiky. Dokladá to aj nasledujúci citát: „Vecne je tento pojem bytia starý a musí byt’ starý, taký starý ako západná filozofia vo svojich dvoch hlavných etapách, ktoré zvonku označujeme párovými menami Parmenides/ Herakleitos - Platon/Aristoteles. Hegelov rozhodujúci krok spočíva v tom, že základné motívy, dopredu určené antickým počiatkom - to logické, egologické a teologické - rozvíja v ich vlastnom bytostnom obsahu. Nový pojem bytia je ten starý, antický v jeho vonkajšom a celkovom naplnení. Preto so spomenutou častou prichádzame k miestu, z ktorého môžeme po prvý krát skutočne podložit, čo a nakol'ko nie je veda Fenomenológie ducha ničím iným ako fundamentálnou ontológiou absolútnej ontológie, a t. j. onto-lógie vôbec." 27

Preto podla Heideggera možno v súlade $\mathrm{s}$ Aristotelom považovat všetky bližšie určenia bytia za kategórie. Aristotelom sa nechal inšpirovat aj Hegel, no na inom mieste, tam, kde Aristoteles vo svojom spise $O$ duši definuje život

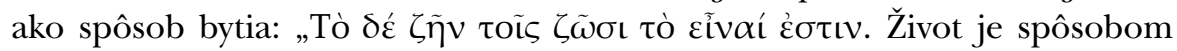
bytia. "28 Rovnako aj Hegel hovori už vo svojich teologických spisoch z mladosti o bytí ako o čistom živote a na rozdiel od Heideggera dáva po celý čas pred pojmom bytia evidentne prednost' pojmu života. Bytie je u Hegela podstatou života, pretože na rozdiel od Heideggera si nevšíma jeho statickú stránku, ktorá je porovnatel'ná s ničím, ale vo svojej dialektike kladie dôraz na pojem diania, ktorý do statického chápania bytia vnáša pohyb a tým aj život. Preto je vo Fenomenológii ducha to skutočné bytie vnímané ako život. ${ }^{29}$

A Heidegger si je tejto odlišnosti zretel’ne vedomý, ked’ tvrdí: „Preto hovorí Hegel: »Bytie už nemá význam abstrakcie bytia [tak ako sféra predmetnosti vedomia], ani jej čistú bytnost', abstrakciu všeobecnosti; ale jej bytie je práve tak jednoduchou tekutou substanciou čistého pohybu v sebe samej.«"30 Ak sa Heidegger s Hegelom nezhoduje v chápaní bytia, potom sa následne obaja myslitelia nezhodnú ani na tom, ako je potrebné chápať čas. Heidegger na

27 M. Heidegger, Hegels Phänomenologie des Geistes..., s. 204.

28 Tamže, s. 206.

29 Tamže.

30 Tamže, s. 207. 
túto skutočnost’ upozorňuje v časti, kde sa odvoláva na svoje klúčové dielo, Bytie a čas. Konštatuje: „Ak je vysvetlovanie problematiky »Bytia a času« niekde iste protichodné, tak je to pri Hegelovi. Lebo téza: Bytnostou bytia je čas - je práve protiklad toho, čo sa Hegel pokúšal v celej svojej filozofii dokázat'. Potom ale musí hegelovská téza zniet opačne: Bytie je podstata času, a síce bytie qua nekonečnost'. A práve toto stojí jasne a zretel'ne na uvedenom mieste »Fenomenológie«"“31

Navyše o rozdielnosti v celkovom chápaní problému bytia svedčí aj spôsob, akým obaja myslitelia používajú pojem Wesen. Kým u Hegela je Wesen tradične podstatou, u Heideggera nadobúda ten istý pojem význam bytnosti. U Hegela je teda život bytím a bytie je prekonávaním vnútorných a tým aj časových rozdielov, a tak dosahovaním nekonečnosti. Podstata bytia je tak u Hegela aj podstatou času, pričom toto chápanie nie je podla Heideggera iba ontologické alebo onto-teo-logické, ale rovno onto-teo-ego-logické, ked’že je založené na sebaidentite $v$ inakosti, vyjadrenej ako Ja = Ja.

„Súborne,“ tvrdí Heidegger, „môžeme v tézach povedat: Hegel - bytie (nekonečnost') je tiež podstatou času. My - čas je pôvodnou bytnostou bytia. Toto nie sú jednoducho antiteticky protichodne postavené tézy, ale >bytnoste $<$ tu zakaždým znamená niečo podstatne odlišné práve preto, lebo bytie je tu pochopené inak. Bytnost’ sama je teda len následný doklad porozumenia bytiu a jeho pojmu. " ${ }^{22} \mathrm{Z}$ uvedeného je zrejmé, že Heideggera vo Fenomenlógii ducha nezaujíma ani tak problematika sebauvedomenia, ale omnoho viac sa snaží o vyvodenie záverov, ktoré by dokázali, že Hegelov pojem bytia spadá do oblasti onto-teo-lógie. Celá Heideggerova interpretácia Fenomenológie ducha tak predstavuje neustálu konfrontáciu medzi Hegelovým, ontoteologickým a Heideggerovým vlastným, nemetafyzickým a podla neho samého jediným filozoficky prípustným chápaním pojmu bytia.

\section{Záver}

Kým Heidegger sa zaoberá Fenomenológiou ducha ako vedou o skúsenosti vedomia vo svojich prednáškach z rokov 1942/43 a d’alej sa jej už nevenuje, Patočka, ktorý tento Heideggerov spis nepochybne poznal, si z takejto interpretácie urobil východiskovú pozíciu pre celkové skúmanie Hegelovho textu,

31 Tamže, s. 209.

32 Tamže, s. 211. 
a to hned' v Úvode k svojmu prednáškovému cyklu o Fenomenológii ducha, kde píše: „Fenomenologie ducha, bylo ukázáno, není ničím jiným, než jasnejším, otevřenejším vyjádřením toho, co znamená zkušenost vědomi. “33 Tým, na rozdiel od Heideggera, dáva Fenomenológii ducha už od začiatku silne antropologický charakter, ktorý sa s každou d’alšou stranou jeho prednáškového cyklu ešte zvýrazňuje, a to najmä tým, že Patočka používa pri výklade problémov, obsiahnutých vo Fenomenológii ducha, aj Hegelove rané, teologické spisy. Heidegger, na rozdiel od Patočku, od začiatku pristupuje priamo k textu Fenomenológie ducha a texty raného Hegela prakticky ignoruje, čím bráni zasadeniu samotnej Fenomenológie ducha do širšieho dejinno-filozofického a interpretačného kontextu. Prekonanie neštastného vedomia je tak pre Patočku zjednotením l’udského s božským, zatial' čo v Heideggerovom výlučne ontologickom chápaní predstavuje zjednotenie jestvujúcna s bytím.

Pre Heideggera potom Hegel spája poznanie veci osebe, podstaty, s poznaním veci pre nás. $\mathrm{V}$ tomto absolútnom poznaní je vystihnutá podstata vedy o duchu, kde jav a podstata javu, kde predmet a pojem, ktorý ho označuje, sú vždy jedným, pretože si navzájom zodpovedajú. „Pro tuto nutnost je tato cesta $\mathrm{k}$ věde již sama vědou a podle svého obsahu je tedy vědou o zkušenost $i$ vědomi. “34 Patočka podrobne rozoberá aj centrálny motív Hegelovej filozofie dejín, a to dialektiku pána a rába, ktorá úzko súvisí práve s problémom sebauvedomenia a sebapoznania človeka. ${ }^{35}$ Kým pre mnohých myslitelom je práve toto jeden z najpodstatnejších problémov Fenomenológie ducha, Heidegger si tento motív opät vôbec nevšíma, lebo do jeho ontologického reflektovania sa nedá zmysluplne zahrnút.

Problematika pána a rába predstavuje jeden z dôležitých pilierov hegelovského humanizmu, ked’že predstavuje spôsob, akým možno odstránit prekážku zavŕšenia sebauvedomenia v intersubjektivite, teda vo vzájomnom uznaní dvoch rozličných subjektov, ako správne podotýka Sinnerbrink, a zároveň zdôrazňuje, že tento aspekt Hegelovej filozofie je Heideggerovi úplne cudzí. Pre Heideggera po Bytí a čase strácajú otázky človeka svoj význam tým viac, čím väčšmi sa dostáva do popredia otázka bytia. Možno teda tvrdit, že kým Hegelovi išlo vo Fenomenológii ducha o vztah človeka, poznávajúceho

33 Jan Patočka, Úvod k Hegelově Fenomenologii ducha. Archiv Jana Patočky, Praha. Signatura 3306-I, 1/III/1.

34 G. W. F. Hegel, Fenomenologie ducha..., s. 103.

35 J. Patočka, Hegelova Fenomenologie ducha. Přednáškový cyklus na FF UK 1949/1950. Archiv Jana Patočky, Praha. Signatura 3306-I, s. 1. Pozri k tomu aj R. Stojka, Patočkova filozofia dejin, Druhé doplnené vydanie, Košice: UPJŠ 2015, s. 30-42. 
subjektu, schopného sebauvedomenia, k absolútnu, tak Heideggerovi v jeho interpretácii Hegelovej Fenomenológie ducha išlo predovšetkým o absolútno samé, teda o bytie, ako ho chápal.

Kým Fenomenológia ducha ako prvá časṫ Systému vedy predstavuje prvotný argument v prospech nekonečnosti subjektu, tak jej definitívnym potvrdením by mala byt’ až jeho druhá čast', Logika. Tej ale Heidegger, paradoxne, nevenuje dostatočnú bádatel'skú pozornost'. Pre Heideggera nie je problematika, obsiahnutá vo Fenomenológii ducha, ničím iným ako artikuláciou protikladu: nekonečnost' bytia verzus konečnost' jestvujúcna. Toto je pre Heideggera riešenie otázky bytia, alebo aspoň hladanie riešenia tejto otázky. Metafyzika nedokáže, podla Heideggera, spolahlivo rozlišovat medzi nekonečnostou bytia a konečnostou jestvujúcna, preto je podla neho potrebné a nanajvýš plodné, kriticky sa vyrovnat's Hegelovou dialektikou v kontexte západnej filozofickej tradície. Otázkou ale nad’alej zostáva, nakol'ko sa to Heideggerovi v jeho prehnane ontologizujúcom chápaní Fenomenológie ducha skutočne podarilo.

Táto práca bola podporovaná Agentúrou na podporu výskumu a vývoja na základe zmluvy $\check{c}$. APVV-14-0706.

\section{PhDr. Kristína Bosáková, PhD.}

Katedra filozofie a dejín filozofie

Filozofická fakulta, Univerzita Pavla Jozefa Šafárika

Moyzesova 9, 04001 Košice, Slovenská republika

kristina.bosakova@upjs.sk 